[Agr. Biol. Chem., Vol. 32, No. 9, p. 1190 1192, 1968]

\title{
Effect of Molybdenum, Vanadium and Tungsten on the Activity of Nitrobacter agilis
}

\author{
By S. P. Tandon and M. M. Mishra
}

Chemistry Department, University of Allahabad, Allahabad, India

Received April 10, 1968

Nutritional studies have indicated that the growth requirements of Nitrobacter include calcium, " iron, phosphorus and magnesium. ${ }^{21}$ Zavarzin $^{31}$ was the first to note that Mo echances the development of Nitrobacter in freshly inoculated cultures as measured by nitrite oxidation. Later on Finstein and Delwiche $^{4}$ found that Mo is essential for Nitrobacter and maximum grow th takes place when it is present in the concentration of $10^{-9} \mathrm{~g}$ moles/litre. They estimated that a minimum of 2000 atoms of Mo is required for the synthesis of one Nitrobacter cell. Mo has proved to be essential for every reaction in the nitrogen cycle. It has been observed that for some organisms (viz-Azotobacter), vanadium can serve the same purpose as Mo, but for others (such as Beijerinckia), it can not.

\section{EXPERIMENTAL}

The following solutions were prepared:

(i) Culture medinm-The composition of the culture medium employed was as follows:

$\mathrm{Na}_{2} \mathrm{CO}_{3} 1.0 \mathrm{~g}, \mathrm{~K}_{2} \mathrm{HPO}_{4} 0.5 \mathrm{~g}, \mathrm{NaCl} 0.5 \mathrm{~g}, \mathrm{CaCl}_{2}$. $6 \mathrm{H}_{2} \mathrm{O} \quad 0.3 \mathrm{~g}, \quad \mathrm{MgSO}_{4} \cdot 7 \mathrm{H}_{2} \mathrm{O} \quad 0.3 \mathrm{~g}$ and distilled water $1000 \mathrm{ml}$.

To avoid the deficiency of some other micro-

1) T.Y. Kingma-Boltjes, Arch. Micrnbinl., 6, 79 (1935).

2) M. I. H. Aleem, and M. Alexander, Appl. Microbiol. 8, 80 (1960).

3) G. A. Zavarzin, Dokl. Akad. Nauk. S.S.S.R., 113, 1361 (1957).

4) M.S. Finstein and C. C. Delwiche, J. Bacteriol, $\mathbf{8 9}, 123$ (1965). nutrients, the following salts were added at approx. $10^{-5} \mathrm{~g}$ moles per litre concentration:

$\mathrm{ZnSO}_{4}, \mathrm{CuCl}_{2}, \mathrm{Ni}\left(\mathrm{NO}_{3}\right)_{2}, \mathrm{Co}\left(\mathrm{NO}_{3}\right)_{2}$ and $\mathrm{FeSO}_{4}$. $7 \mathrm{H}_{2} \mathrm{O}$

(ii) Sodium nitrite solution containing $1 \mathrm{mg}$. nitrogen per $\mathrm{ml}$.

(iii) Ten solutions of each of $\mathrm{Na}_{2} \mathrm{MoO}_{4} \cdot 2 \mathrm{H}_{2} \mathrm{O}_{1}$ $\mathrm{NaVO}_{3}$ and $\mathrm{Na}_{2} \mathrm{WO}_{4}$ were prepared in such a way that when $5 \mathrm{ml}$ of each were added to $45 \mathrm{ml}$ medium, their concentration in the medium was $10^{-1}, 10^{-2}, 10^{-3}, 10^{-4}, 10^{-5}, 10^{-6}, 10^{-7}, 10^{-8}, 10^{-9}$ and $10^{-10} \mathrm{~g}$ mole $M o$ or $V$ or $W$ per litre respectively.

To study the effect of Mo on the oxidation of nitrite by Nitrobacter agilis, ten $250 \mathrm{ml}$ conical flasks were taken; $40 \mathrm{ml}$ culture medium and $0.2 \mathrm{ml}$ sodium nitrite solution were added to each flask. Then $5 \mathrm{ml}$ of the respective solution of sodium molybdate were added separately to obtain a concentration of $\mathrm{Mo}$ at $10^{-2}, 10^{-3}, 10^{-4}, 10^{-5}, 10^{-6}, 10^{-7}$, $10^{-8}, 10^{-9}$ and $10^{-10}$ respectively in these flasks. One flask was left as such with no molybdate solution. The volume of the solution of each flask was made up to $49 \mathrm{ml}$ by adding the requisite amount of distilled water. All the flasks were sterilized at 15 lbs. pressure for $30 \mathrm{~min}$. After cooling I ml of inoculum of pure culture of Nitrobacter agilis was added to each flask and all the flasks were then kept in an incubater at $32^{\circ} \mathrm{C}$. For the preparation of pure culture the medium used was the same as has been described above [(i) Culture medium]. The amount of nitrite nitrogen (Griess-Ilosovay method) ${ }^{51}$ and the total of nitrite and nitrate nitrogen (Brucine method) ${ }^{6}$ ?

5) J. Meiklejohn, J. Gen. Microbiol., 4, 185 (1950).

6) F. L. Fisher, E. R. Ibert and H. F. Beckman, Anal. Chem., 30, 1972 (1958). 
in $1 \mathrm{ml}$ of the inoculum were estimated at the beginning of the experiment after introducing it into a flask containing $40 \mathrm{ml}$ medium and $10 \mathrm{ml}$ distilled water. The inoculum contained $0.003 \mathrm{mg}$ nitrogen as nitrite nitrogen and $0.06 \mathrm{mg}$ as the total of nitrite and nitrate nitrogen per $\mathrm{ml}$.

Similar experiments were set up to study the effect of $\mathrm{V}$ and $\mathrm{W}$.

To studp the effect of $\mathrm{V}$ and $\mathrm{W}$ in presence of Mo, similar experiments were set up, but here in every flask $5 \mathrm{ml}$ of sodium molybdate solution was added so as to obtain a concentration of Mo in each flask at $10^{-8} \mathrm{~g}$ moles/litre.

Table I. EFFEct of Mo ON THE OXIDATION OF NiTRITE BY Nitrobacter agilis

\begin{tabular}{ccccc} 
Conc. of Mo & \multicolumn{4}{c}{$\begin{array}{c}\text { Amount of nitrite nitrogen left at } \\
\text { different intervals of time (in mg) }\end{array}$} \\
\cline { 3 - 4 } & \multicolumn{4}{c}{ Time in hours } \\
Control & 24 & 72 & 168 & 240 \\
$10^{-2}$ & 0.176 & 0.074 & 0.007 & - \\
$10^{-3}$ & 0.184 & 0.097 & 0.021 & - \\
$10^{-4}$ & 0.180 & 0.068 & - & - \\
$10^{-5}$ & 0.176 & 0.058 & - & - \\
$10^{-6}$ & 0.169 & 0.054 & - & - \\
$10^{-7}$ & 0.167 & 0.049 & - & - \\
$10^{-8}$ & 0.167 & 0.047 & - & - \\
$10^{-9}$ & 0.167 & 0.045 & - & - \\
$10^{-10}$ & 0.173 & 0.066 & - & - \\
& 0.173 & 0.072 & - & -
\end{tabular}

Control-containing no Mo

TABLE II. EFFECT OF V ON THE OxIDATION oF NITRITE BY Nitrobacter agilis

\begin{tabular}{lcccc} 
Conc. of V & \multicolumn{4}{c}{$\begin{array}{c}\text { Amount of nitrite nitrogen left at } \\
\text { different intervals of time (in mg) }\end{array}$} \\
\cline { 2 - 5 } (g moles/litre) & \multicolumn{4}{c}{ Time in hours } \\
Control & 24 & 72 & 168 & 240 \\
$10^{-2}$ & 0.176 & 0.074 & 0.007 & - \\
$10^{-3}$ & 0.184 & 0.119 & 0.053 & - \\
$10^{-4}$ & 0.180 & 0.085 & - & - \\
$10^{-5}$ & 0.180 & 0.073 & - & - \\
$10^{-6}$ & 0.180 & 0.165 & - & - \\
$10^{-7}$ & 0.176 & 0.056 & - & - \\
$10^{-8}$ & 0.169 & 0.056 & - & - \\
$10^{-9}$ & 0.173 & 0.059 & - & - \\
$10^{-10}$ & 0.176 & 0.071 & - & - \\
& 0.180 & 0.072 & - & -
\end{tabular}

Control-containing no $\mathrm{V}$
The nitrite left was estimated in $10 \mathrm{ml}$ fraction of each flask after $24,72,168$ and $240 \mathrm{hr}$.

The total of Nitrite and nitrate nitrogen was also determined at the end of each experiment to know, if any loss of nitrogen had taken place.

\section{DISCUSSION*}

In agreement with the observations of Finstein and Delwiche, we also found that Mo enhances the rate of oxidation of nitrite to nitrate by Nitrobactor agilis. Table I clearly shows that the rate of nitrite oxidation is less when the concentration of Mo is $10^{-2} \mathrm{~g}$ moles/ litre. But when the concentration is $10^{-3}$ to $10^{-10}$ $\mathrm{g}$ moles/litre, the rate of oxidation increases. Maximum nitrite oxidation takes place when the concentration of $\mathrm{Mo}$ is kept at $10^{-8}$ moles/litre. This indicates that the activity of Nictobacter agilis is maximum at $10^{-8} \mathrm{M}$ concentration of Mo. Finstein and Delwiche found this concentration to be $10^{-9} \mathrm{M}$.

Table II shows that $\mathrm{V}$ behaves very much like Mo but it is slightly less effective in increasing the rate of nitrite oxidation and

TABLE III. EFFECT OF $\mathrm{V}$ ON THE OXIDATION OF NITRITE BX Nitrobacter agilis WHEN Mo IS also PRESENT AT THE CONC. OF $10^{-8} \mathrm{M}$

Amount of nitrite nitrogen left at different intervals of time (in $\mathrm{mg}$ )

Conc. of $\mathrm{V}$ Time in hours (g moles/litre)

$\overbrace{24} \begin{array}{lll}\text { Time in hours } \\ 72 & 168 & 240\end{array}$

$\begin{array}{lllcc}\text { Control } & 0.167 & 0.045 & - & - \\ 10^{-2} & 0.184 & 0.121 & 0.038 & - \\ 10^{-3} & 0.173 & 0.078 & - & - \\ 10^{-4} & 0.171 & 0.053 & - & - \\ 10^{-5} & 0.169 & 0.047 & - & - \\ 10^{-6} & 0.167 & 0.047 & - & - \\ 10^{-7} & 0.167 & 0.043 & - & - \\ 10^{8} & 0.168 & 0.045 & - & - \\ 10^{-9} & 0.167 & 0.046 & - & - \\ 10^{-10} & 0.168 & 0.043 & - & -\end{array}$

Control-containing no $\mathrm{V}$

* The total of nitrate and nitrate nitrogen remained the same at the beginning and at the end of each experiment, which clearly showed that no loss of nitrogen took place and that all the nitrite which disappeared had been changed to nitrate only. 
TABLE IV. EFFECT OF W ON THE OXIDATION OF NITRITE BY Nitrobacter agilis

\begin{tabular}{|c|c|c|c|c|}
\hline \multirow{3}{*}{$\begin{array}{l}\text { Control of W } \\
\text { (g moles/litre) }\end{array}$} & \multicolumn{4}{|c|}{$\begin{array}{l}\text { Amount of nitrite nitrogen left at } \\
\text { different intervals of time (in } \mathrm{mg} \text { ) }\end{array}$} \\
\hline & \multicolumn{4}{|c|}{ Time in hours } \\
\hline & 24 & 72 & 168 & 240 \\
\hline Control & 0.176 & 0.074 & 0.007 & - \\
\hline $10^{-2}$ & 0.191 & 0.160 & 0.117 & 0.052 \\
\hline $10^{-3}$ & 0.187 & 0.131 & 0.066 & - \\
\hline $10^{-4}$ & 0.187 & 0.117 & 0.027 & - \\
\hline $10^{-5}$ & 0.187 & 0.108 & 0.017 & - \\
\hline $10^{-6}$ & 0.184 & 0.095 & 0.009 & - \\
\hline $10-7$ & 0.176 & 0.089 & - & - \\
\hline $10^{-8}$ & 0.179 & 0.087 & - & - \\
\hline $10^{-9}$ & 0.176 & 0.080 & - & - \\
\hline $10^{-10}$ & 0.178 & 0.071 & - & - \\
\hline \multicolumn{5}{|c|}{ Control-containing no $\mathrm{W}$} \\
\hline
\end{tabular}
Conc. of W
(g molef/litre) $\frac{\begin{array}{l}\text { Amount of nitrite nitrogen left at } \\ \text { different intervals of time (in mg) }\end{array}}{$\cline { 2 - 2 }} $\begin{gathered}\text { Time in hours } \\ 24\end{gathered}$

$\begin{array}{lllcc}\text { Control } & 0.167 & 0.045 & - & - \\ 10^{-2} & 0.184 & 0.113 & 0.023 & - \\ 10^{-3} & 0.184 & 0.109 & 0.018 & - \\ 10^{-4} & 0.180 & 0.097 & 0.008 & - \\ 10^{-5} & 0.180 & 0.080 & - & - \\ 10^{-6} & 0.180 & 0.076 & - & - \\ 10^{-3} & 0.176 & 0.074 & - & - \\ 10^{-7} & 0.173 & 0.072 & - & - \\ 10^{-9} & 0.173 & 0.069 & - & - \\ 10^{-10} & 0.169 & 0.067 & - & -\end{array}$

Control-containing no $\mathrm{W}$

the maximum nitrite oxidation takes place when it is present in the concentration of $10^{-7} \mathrm{M}$. When Mo is added along with $\mathrm{V}$, it is found that there is no additional effect.
TABLE VI. EFFECT OF W ON THE OXIDation OF NITRATE BY Nitrobacter agilis WHEN $\mathrm{V}$ Is also Present at THE Conc. of ${ }^{10^{-7}} \mathrm{M}$

\begin{tabular}{|c|c|c|c|c|}
\hline \multirow{2}{*}{$\begin{array}{l}\text { Conc. of W } \\
\text { (g moles/litre) }\end{array}$} & \multicolumn{4}{|c|}{$\begin{array}{l}\text { Amount of nitrite nitrogen left at } \\
\text { different intervals of time (in } \mathrm{mg} \text { ) }\end{array}$} \\
\hline & \multicolumn{4}{|c|}{ Time in hours } \\
\hline & 24 & 72 & 168 & 240 \\
\hline Control & 0.171 & 0.058 & - & - \\
\hline $10^{-2}$ & 0.187 & 0.149 & 0.102 & 0.034 \\
\hline $10^{-3}$ & 0.187 & 1.131 & 0.078 & - \\
\hline $10^{-4}$ & 0.187 & 0.117 & 0.057 & - \\
\hline $10^{-5}$ & 0.182 & 0.113 & 0.053 & - \\
\hline $10^{-6}$ & 0.180 & 0.111 & 0.047 & - \\
\hline $10^{-7}$ & 0.182 & 0.095 & 0.024 & - \\
\hline $10^{-8}$ & 0.173 & 0.082 & - & - \\
\hline $10^{-9}$ & 0.173 & 0.066 & - & - \\
\hline $10^{-10}$ & 0.169 & 0.061 & - & - \\
\hline
\end{tabular}

Control-containing no $\mathrm{W}$

The rate of nitrite oxidation is equal to the rate which obtains in the presence of optimum concentration of Mo alone. This clearly shows that Mo is required for the activity of Nitrobacter agilis only upto a certain amount. In the absence of Mo, $\mathrm{V}$ can serve the purpose of Mo, though not as efficiently as the latter.

It is found that the presence of $\mathrm{W}$ alone in the medium decreases the rate of nitrite oxidation. The decrease is proportional to the concentration of $\mathrm{W}$ in the medium. At such a high dilution of $\mathrm{W}$ as that of $10^{-10} \mathrm{M}$ concentration, the rate is approximately the same which obtains in the medium without any $\mathrm{W}$. It is further observed that when Mo is added along with $\mathrm{W}$, the depressing effect of $\mathrm{W}$ is very much reduced. This indicates that Mo substitutes $W$ and so the latter becomes less active. But when $\mathrm{V}$ is added along with $W$, there is no change in the rate of nitrite oxidation. 